\title{
Problems in Law Number 40 of 2007 the Article 7 on Limited Company in Indonesia
}

\author{
Andreas Albertus Andi Prajitno \\ Lecturer at Faculty of Law, Pelita Harapan University, Jl. Ahmad Yani, Dukuh Menanggal, Surabaya, East Java \\ 60234.
}

\begin{abstract}
To be one of powerful nation, the economic status of a country must be fixed at first. Balance protection and legal certainty is needed to attract more investors to play their treasury in target country. Government starts their role by offering some features to investors by using law. It must offer features that will ease and protect its client to reach mutual benefit. One of features that is offered to investors is UUPT (Limited Company Law). Both domestic and foreign investors will stand equal chance for this legal action which is stated in Law Number 40 of 2007 Article 7 on Limited Company (PT). This paper applies juridical normative technique within statue and historical approach. The result of study revealed that this law number 40 of 2007 article 7 about limited company brings more problems instead of advantages toward investors. The points in its Article against each other, it does not have clear definition on several terms, and it has imbalanced status between right and responsibility especially for foreign investors. These situations will invest more doubt among foreign investors. In conclusion, it is concluded that Law Number 40 of 2007 the Article 7 on Limited Company does not include legal actors in its making especially notary who are the most eligible in company deeds conduction. Moreover, limited time of socialization toward economic actors for this law will bring more confusion and problems instead of simplicity and mutual benefit.
\end{abstract}

Keywords: UUPT no. 40 of 2007 the article 7, legal certainty, benefit and justice principle.

DOI: $10.7176 / \mathrm{JLPG} / 98-19$

Publication date:June 30th 2020

\section{Introduction}

Rapid economic development in Indonesia is very essential in order to face globalization, especially the Asian Economic Community (MEA). As every aspect of life must be supported by rapid economic development, Indonesia needs very strong fundamental economy. One of factor that support the economy status of a country is the movement of investors (Goryakin et al. 2015), both national and international investors who are willing to invest their treasury in Indonesia. Monetary treasury foundation of a country will be strong if the economy and security status of the country is normal, and that a trade agreement between ASEAN countries must be established as well through infestation. Indonesia must possess minimum level in order to compete with other ASEAN countries.

Asian Economic Community is the starting point for ASEAN country to face other countries especially the super power countries (Keling et al. 2011). Indirectly, it will affect ASEAN countries to compete each other to develop their economy faster. The environment of infestation in Indonesia must be healthy by providing guarantee on every law aspect, such as: law of taxation, trading, politic stabilization sector, etc. Thus, the actor of investor is needed from both national and international investors, it must have beneficial relationship and strong commitment for both government and investors in Indonesia.

The current law that regulates limited company, in order to invest in Indonesia, is regulated in civil law (BURGERLIJK WEETBOOK/BW) which is supported with KUHD Law of Trade (WEETBOOK Van KOOPHANDEL /W.v.K), namely: (1) UD (Small Enterprise); (2) Fa (Firm), regulated in KUHD article 16-35; (3) CV (Comanditaire Vennootschap), regulated in KUHD article 19-21; (4) N.V. (NAAMLOZE VENNOTSCHAP), regulated in KUHD article 36-56, it is now known as PT (Limited Company) which is regulated in UUPT number 1 of 1995, it is revised in UUPT number 40 of 2007.

There are several problems in implementing the law of limited company which is significant enough and complex especially for the Article 7. The Article 7 Act 1, 5, and 6 will make the investors reconsider their decision because it will affect their treasury in partnering from the start when the shareholder number is only one investor. Hence, this study focused on two matters, namely the reasoning for the implementation of limited company law the Article 7 in creating harmful for the investors, and to examine whether the Article 7 contain injustice and unreliable outcome.

\section{Literature Review}

Principle is the basic foundation of cognitive process. Principle is also known as basic regulation. According to Rahardjo (1986), principle of law is the soul of law regulation, because it represents as starting point of a new born law. Principle of law is the legal ratio of regulation, which is universal, abstract, and general, the basic mind of concrete rules and can be found by looking for common characteristics in concrete rules. The function of principle 
of law is to support law system in order to make it to be more flexible (Mertokusumo 1986). Basically, law system is already perfect, but the concrete regulation does not always perfect, and the principle of law will support its concrete part. Principle of law has double function which are as foundation of positive law system and as critical guinea pig toward positive law system (Scholten 1935).

Norms in the Great Indonesian Dictionary (KBBI) are interpreted as First: rules or regulations that bind group citizens in the community are used as guidelines, order and control of appropriate and accepted behavior, second: Rules, Measures, or Rules used as benchmarks to judge or compare things. Legal norm is regulations conducted by government that binds every person and actors, it could be used as oppressed tools by tools of the nations, and the source is constitution law (Muliono 1989). In this case, the constitution law about Limited Company is Law Number 40 of 2007 the Article 7, which the article creates problems. In order to overcome it, several principles are used to reconsider disadvantages from the articles.

\subsection{Free Contract Making Decision}

Trade agreement principle of Indonesia follows free contract principle, which is regulated in KUHP Civil Law article 1338, it is stated that every legal decision contract is used as legal regulation for those who are agreed.

\subsection{Justice Principle}

Justice, according to Aristoteles, "Justice is an act that lies between too much giving and too little that can be interpreted is giving something to everyone whereas giving what is rightfully theirs " (Rasuanto 2005). Justice is one of goal of law. The definition of law is the balance of what you take and what you give, both advantage and disadvantage, which can also be interpreted as giving rights equal to a person's capacity or proportional enforcement of each person.

\subsection{Legal Certainty Principle}

It is interchangeable with norm certainty; thus, it could be used as guidance for society who must follow the law. It could be interpreted as thing that is determined by concrete law (Apeldoorn 1990). Legal certainty is judiciable protection toward arrogant action that some people will use abusive power to claim what they want (Wantu 2007).

\subsection{Benefit Principle}

Legal advantage must be considered because every person will expect good deeds in law enforcement result, it must give advantage toward society. A good law is a law who give positive benefit for its legal subject.

\section{Method}

This study used the normative juridical with historical approach. Normative Juridical was a research type that overcame previous staged question and it followed certain scientific procedure in order to find true logic of law from normative perspective. Simply said that the normative legal study included the principle of law, the systematic study of law, level of law synchronization, legal history, and comparative law (Christiani 2016). This study involved law sources material, namely the Law Number 40 of 2007 about Limited Company (PT) and government's regulation related to it. The data were collected through legal sources and interview with public notary, and analyzed by using theoretical concepts of related theories in legal studies. This study's concept has a significant empirical side, because it could contribute in the legal practice when it did not explain about a fact (Nalle 2015).

\section{Result and Discussion}

The Law of Limited Company in the Article 7 stated that:

- Company is run by two or more people with notary deed written in Indonesia language.

- Every shareholder is mandatory to take stock portion when the company is commenced.

- As previously stated in act (2), it could not be applied during merge.

- Company will receive its legal status on the date it was published by ministry which is responsible for its business type.

- After company receive its legal status and shareholders number become two (2) people, no more than six (6) months started from its event date, the shareholders are mandatory to move part of their stock portion to other people, or the company publish new stock for other people.

- After the time event stated in act five (5) and the shareholders number are still no more than two (2) people, the shareholders will be fully responsible for every loss of the company, and by the name of government, state court could dismiss the company.

- $\quad$ The condition that stated company must be hold by two shareholders or more shich is stated in act one (1), five (5), and six (6), will not be qualified for: 
$>$ Company which all of its asset is owned by country, or;

$>$ Company that run stock exchange, loan and mortgage, bank, and other institution which is stated in Stock Market law.

In order to start limited company in Indonesia, according to UUPT article 7 act 1 point 1 , it stated that Company is run by two or more people with notary deed written in Indonesia language. The implementation is often followed by problems especially for foreign investors who want to invest their money to Indonesia (Melisa et al. 2017), because the law does not mention limited company can be run by one person and single shareholder.

In reality, it is hard to find partner who share similar vision and mission. Such problems will lead into subjective conclusion or public deception by using shadowing partner which is available to be seen in contra letter. Contra letter deed is two deeds that contains contrast explanation or does not provide true information. It becomes one of law violation especially UUJN namely borrowing the name of share ownership, generally the person borrowed name who has a very small share and ultimately tends to be diluted (the strong beat the weak "Homo Homini Lopus"), or a large share ownership but made a contra letter deed including deed of recognition of debt to other company when in fact it is not in debt only in fact borrowed by name and the deed of borrowing the name contains a share ownership that is not himself.

Control of the company although determined by the voice of shares when owned by more than one tendency to dispute to determine or decide on company policy will be more difficult, especially the private element family company is inevitable. The existence of the aforementioned can lead to negligence and there is no responsibility from the management or shareholders that are not real (pseudo) and prone to disputes between shareholders in making decisions to run the company both administratively and operationally. In addition, tax manipulation can occur by means of small shareholding in connection with the Limitation of Taxable Subjects Cause uncertainty about share ownership.

On the other hand, the implementation of the Article 7 Act 5 and 6 stated:

After company receive its legal status and shareholders number become two (2) people, no more than six (6) months started from its event date, the shareholders are mandatory to move part of their stock portion to other people, or the company publish new stock for other people.

If Act 5 is occurred, then Article 7 Act 1 will be implemented as well. The act in this article does not have legal certainty about company owner must be run by one legal subject (people/legal council), but it can be concluded that it can be run by one owner even though only for limited period of time which is six months within full responsibility is still carried by the shareholder who is single handedly run the company because they could not find any appropriate partner yet. Thus, it will result the same situation as mentioned in Article 7 Act 1 . Moreover, this article violates human rights about the mandatory to move the treasury to another legal subject. Meanwhile, the implementation of the Act 6 stated:

After the time event stated in act five (5) and the shareholders number are still no more than two (2) people, the shareholders will be fully responsible for every loss of the company, and by the name of government, state court could dismiss the company

This act will put the same level between investors and single shareholder and they must carry full private responsibility for the company. The word 'private' is not clearly defined, it could mean by taking responsibility as much as the number of stocks in shareholder or it could also mean the private treasury outside stock portion that they invest in limited company. VOOGE NORM (uncertainty) in the word 'private' and injustice of responsibility portion which is carried by single shareholder that occurs outside of their favor.

This event will lead into legal uncertainty that will fill investors with doubt who are afraid of losing their stock portion if they tend to invest their treasury in this country. Moreover, after six months of the event, government has right to dismiss the company which will greatly suffer investors because of some matters, namely:

- Limited company must sell their stock to legal subjects who are stranger to single shareholder;

- Shareholder must pay operational bill including existing debt;

- Dismissing limited company is an arrogant act.

In order to overcome this, contra letter is applied in such situation as the Article 7 Act 7 that stated:

- The condition that stated company must be hold by two shareholders or more which is stated in act one (1), five (5), and six (6), will not be qualified for:

- Company which all of its asset is owned by country, or;

- Company that run stock exchange, loan and mortgage, bank, and other institution which is stated in Stock Market law.

The exception of single shareholder ownership is the owner by government which is regulated in article 7 act 7 point 1 is acceptable, but it could only apply for limited company who run its business in stock exchange, and other institution which is mentioned in stock market law, loan and mortgage, bank, and other institution which is stated in Stock Market law, it must not be one of the exceptions. The word 'expired' becomes power abuse because differentiation of enforcement because the limited liability company formed is the same and is no different from the establishment of a limited liability company in general. 
In this equity principle event, all action of discrimination and all of its manifestation are considered as violation to law, except for special and temporary actions which is called affirmative action. It is essential for affirmative action that it could enhance development and catch up with other super power countries. Some business is considered as affirmative action without discrimination action (Appel et al. 2005), such as limited company owned by BUMN, it could use affirmative action without discrimination outcome. Thus, this article is injustice matter. The definition of differentiation is not clear both its manner and function; unknown advantages and irresponsible law.

The Article 7 does not provide legal certainty and legal protection that could invest more doubt for foreign investors who are willing to invest their treasury in peaceful Indonesia. Domestic and foreign investor will not ask for legal certainty, legal protection, simplicity, facility and others. That is why, government must perform quick action in fulfilling the needs for economic actors by providing them with reliable law that meet their needs and time. Thus, government, foreign investors, and domestic investors could build their synergy up within faithful and beneficial relationship.

The implementation of Article 7 tends to be an obstacle and can even be detrimental to investors (Investors) because in the course of business it can interfere at any time smoothness operation of the company, because it can cause problems regarding company control based on or determined by the number of shares that are not allowed to be owned by one person / legal entity (single share ownership). Article 7 paragraph (1) does not have any legal consequences if it is established by one person or more than one person proven by the existence of Article 7 Paragraph 5 and 6 and when juxtaposed with the Article 7 Paragraph 7 Point 2 will be seen clearly unfounded injustice.

The limited Company Law Article 7 is full of confusion due to obscurity, there are different rules that are contradictory in one article, uncertainty, no justice and burdensome to the founder of the company can even harm the founder (Nugraha \& Katherina 2019; Wahyuni 2017). In one hand, such event is not possible because law must scale in same level for every people within equity of rights and responsibility. In theory of law, implementation of law should possess use principle, legal certainty, justice, and equity before law principle.

Government program meant to attract as many as possible investors to Indonesia, both foreign and domestic investors. It must be supported with legal certainty of equal right and responsibility for mutual benefit between government and investors. All of them are mentioned in limited company law. Unfortunately, implementation of article 7 does not attract investors, especially the foreign investor because of:

- It will break the law in starting point by using contra letter deed that identify deception along the way of the company.

- The law against each other between the Article 1 and 7 point $b$, and if the law is implemented, investors and single shareholder would not affect government.

- The Act 6 has misinterpretation possibility with the word 'private'. The Article 7 will definitely harm investors as it touches their private treasury point.

Those uncertain legal and injustice outcomes will lead this nation into more problems. Disputes could not be avoided as operational company will be stopped and harm foreign investors and shareholders. The article is conducted without presence of legal actor especially notary as most responsible in making company deeds.

\section{Conclusion}

Implementation of limited company law number 40 of 2007 Article 7 will create more problems and harm country or investors of limited company, because of (1) the norms making does not include legal actors who are qualified in corporation deed conduction, the notary; and (b) the limited amount of socialization toward economic actors which is the investors.

Based on explanation above, the writer suggests:

- Changing the article that allow owner of limited company could be one person only, the modified law will state:

$>$ The company is run by one legal subject within notary deed written in Indonesian language.

$>$ Every shareholder must take stock portion of the company.

$>$ As stated in act 2, it could be used in merge action.

$>$ The company will receive its legal status right after publication of ministry decision about company legal status.

- Law modification could implement by:

$>\quad$ Law making must include economic and legal (notary, legal judge, police, and prosecutors) actors.

An effective and efficient socialization toward economic actors at least three (3) month before the publication of the law (in accordance with publicity principle)

\section{References}

Apeldoorn, V. (1990), “Pengantar Ilmu Hukum”, Jakarta, Pradya Paramita. 
Appel, R. N., Gray, A. L., Loy, N. (2005), “Affirmative Action in the Workplace: Forty Years Later”, Hofstra Labor \& Employment Law Journal 22(549), 549-574.

Christiani, T. A. (2016), "Normative and Empirical Research Methods: Their Usefulness and Relevance in the Study of Law as an Object", Procedia Social and Behavioral Sciences 219(2016), 201-207.

Goryakin, Y., Lobstein, T., James, W. P. T., Suhrcke, M. (2015), "The Impact of Economic, Political and Social Globalization on Overweight and Obesity in the 56 Low and Middle Income Countries", Social Science \& Medicine 133(2015), 67-76.

Keling, M. F., Hishamudin., Saludin, M. N., Shuib, M. S., Ajis, M. N. (2011), “The Development of ASEAN from Historical Approach", Asian Social Science 7(7), 169-189.

Melisa, G., Yahya, A., Syahbandir, M. (2017), "Kendala dan Hambatan dalam Pelaksanaan Penanaman Modal di Kawasan Perdagangan Bebas dan Pelabuhan Bebas Sabang”, Law Journal 1(3), 1-15.

Mertokusumo, S. (1986), "Mengenal Hukum”, Yogyakarta, Liberty.

Mertokusumo, S. (1996), "Penemuan Hukum: Suatu Pengantar", Yogyakarta, Liberty.

Muliono, A. M., et al. (1989), "Kamus Besar Bahasa Indonesia”, Jakarta, Balai Pustaka.

Nalle, V. I. W. (2015), “The Relevance of Socio-Legal Studies in Legal Science”, Mimbar Hukum 27(1), $179-192$.

Nugraha, X., \& Katherina, A. M. F. (2019), “Tanggungjawab Promotor Perseroan Terbatas Terhadap Kontrak Pra Inkorporasi di Indonesia", Media Iuris 2(1), 127-156.

Rahardjo, S. (1986), "Ilmu Hukum”, Bandung, Alumni.

Rasuanto, B. (2005), "Keadilan Sosial: Pandangan Deontologis Rawls dan Habermas, Dua Teori Filsafat Politik Modern", Jakarta, Gramedia.

Scholten, P. Rechtsbeginselen. In Verszamelde Geschriften, quoted from J.J.H. Bruggink. (1999), "Refleksi tentang Hukum" translated by Arief Sidharta. Bandung, Citra Aditya Bakti, 1935, 119-120.

Wahyuni, V. T. (2017), “Kepemilikan Tunggal Badan Hukum Perseroan Terbatas (PT)”, Jurnal Hukum Novelty 8(2), 201-215.

Wantu, F. M. (2007), “Antinomi dalam Penegakan Hukum oleh Hakim”, Jurnal Berkala Mimbar Hukum 19(3), 193. 